\title{
Health Problems During and After Travel: A Prospective Observational Study in a Travel Clinic in Portugal
}

\author{
Problemas de Saúde Durante e Após a Viagem: Um \\ Estudo Observacional Prospetivo Numa Consulta de \\ Viajante em Portugal
}

\author{
Cláudia CONCEIÇÃO $\rrbracket^{1}$, Márcia MEDEIROS ${ }^{1}$, Nélia PEREIRA², Luzia GONÇALVES ${ }^{1,3}$, Abílio ANTUNES $^{2}$, \\ Ellen BLONDÉ ${ }^{2}$, Rosa TEODÓSIO ${ }^{1}$, Carlos ARAÚJO ${ }^{2}$, Filomena PEREIRA ${ }^{1}$ \\ Acta Med Port 2021 Dec;34(12):842-850 - https://doi.org/10.20344/amp.14098
}

\section{ABSTRACT}

Introduction: In order to improve the health of travellers during travel it is important to better understand the health problems faced by travellers in different destinations. The main objective of this study was to characterise the perceived health problems of travellers during and up to six months after travel on a pre-travel clinic in Lisbon, Portugal.

Material and Methods: This is a prospective observational study. Participants were recruited among those travellers attending a pretravel clinic between May 2016 and April 2017, meeting the inclusion criteria (age over 18 years old and predicted time of stay from five to 90 days). Structured questionnaires were applied by telephone interviews, three and six months after arrival. Associations and their magnitude were sought between travel and traveller's characteristics with total and specific health problems, using multiple logistic regression models.

Results: Out of 364 participants who completed the study, $60 \%$ were under 37 years of age, and $87.9 \%$ presented a higher educational degree. Africa and Asia were travel destinations for $89.1 \%$ of travellers. Three months after travel, $39.3 \%$ confirmed some travel-acquired health problem, namely diarrhoea (26.6\%) and unmeasured fever (12.4\%). A malaria case was diagnosed, occurring 3.5 months after return. From a total of 189 travellers to countries with high risk of malaria and chemoprophylaxis recommendation, $65.6 \%$ adhered completely and $6.9 \%$ of those presenting fever during travel sought healthcare.

Discussion: The proportion of travellers that became ill was lower compared to other published studies. Failure to follow a random sampling method and the characteristics of the travel consultation with a particular profile of travellers in terms of level of education and ability to pay, challenges the external validity of the study.

Conclusion: Health problems during or after travel occurred in $39.3 \%$ of travellers with diarrhoeal disease being the most common $(26.6 \%)$. From our findings, the need for taking chemoprophylaxis for malaria or seeking health care in the presence of fever is not translated into appropriate action. The reasons are unclear and should be the subject of further research. Furthermore, research is needed with inclusion of other centres practicing travel medicine in Portugal, both in the pre-travel setting and others, in order to better understand the health risks associated with Portuguese traveller's characteristics and destinations.

Keywords: Antimalarials; Diarrhea; Malaria; Portugal; Travel Medicine; Travel-Related IIIness; Vaccination

\section{RESUMO}

Introdução: De forma a melhorar a saúde dos viajantes é necessário compreender os principais problemas de saúde enfrentados em diferentes destinos. O principal objetivo deste estudo foi caracterizar os problemas de saúde relatados por pessoas que recorreram a uma consulta do viajante em Lisboa durante e até seis meses após a viagem.

Material e Métodos: Este é um estudo observacional e prospetivo. Os participantes foram recrutados entre os viajantes que compareceram na consulta entre maio de 2016 e abril de 2017, de acordo com os critérios de inclusão (idade igual ou superior a 18 anos e o tempo previsto de permanência em viagem de cinco a 90 dias). Os questionários estruturados foram aplicados por entrevistas telefónicas, três e seis meses após a chegada. Usando vários modelos de regressão logística, foram procuradas associações entre as características das viagens e dos viajantes com os problemas de saúde totais e específicos, e determinada a sua relevância.

Resultados: Dos 364 participantes que completaram o estudo, $60 \%$ tinham menos de 37 anos de idade e $87,9 \%$ tinham um curso superior. As regiões de África e da Ásia foram os destinos de viagem para $89,1 \%$ dos viajantes. Três meses após a viagem, $39,3 \%$ dos viajantes relataram algum problema de saúde nomeadamente diarreia $(26,6 \%)$ e febre $(12,4 \%)$. Foi diagnosticado um caso de malária 3,5 meses após o regresso. Num total de 189 viajantes para regiões com indicação para quimioprofilaxia de malária, 65,6\% tiveram uma adesão completa e $6,9 \%$ procuraram cuidados de saúde, no caso de febre durante a viagem.

Discussão: A proporção de viajantes que adoeceu foi menor do que noutros estudos publicados. O não cumprimento de um método de amostragem aleatória e as características desta consulta de viajante, que apresenta um perfil específico de viajantes em termos de nível de escolaridade e capacidade de pagamento, colocam em causa a validade externa do estudo.

Conclusão: Os problemas de saúde, durante ou após a viagem, ocorreram em 39,3\% dos viajantes, sendo que a diarreia é o problema mais frequente $(26,6 \%)$. A não adesão a recomendações carece de melhor caracterização. É necessário realizar este tipo de estudo em viajantes que não vão a consultas de aconselhamento antes da viagem e noutros centros de medicina do viajante, de forma a melhor caracterizar os riscos de doença associados a diferentes características e destinos dos viajantes portugueses.

Palavras-chave: Antimaláricos; Diarreia; Doença Relacionada a Viagens; Malaria; Medicina do Viajante; Portugal; Vacinação

1. Global Health and Tropical Medicine. Instituto de Higiene e Medicina Tropical. Universidade NOVA de Lisboa. Lisboa. Portugal.

2. Associação para o Desenvolvimento da Medicina Tropical. Instituto de Higiene e Medicina Tropical. Universidade Nova de Lisboa. Lisboa. Portugal.

3. Centro de Estatística e Aplicações da Universidade de Lisboa. Lisboa. Portugal.

$\triangle$ Autor correspondente: Cláudia Conceição. claudiaconceicao@ihmt.unl.pt

Recebido: 11 de maio de 2020 - Aceite: 17 de setembro de 2020 - First published: 03 de março de 2021 - Online issue published: 02 de dezembro de 2021

Copyright @ Ordem dos Médicos 2021 


\section{INTRODUCTION}

A It is important to better understand the health problems faced by travellers in different destinations, in order to improve travellers' health during travel. Studies based on healthcare demand in travel health clinics or using data from surveillance systems on imported infectious diseases are relevant, but do not convey the proportion of travellers that became ill during or after travel. ${ }^{1,2} \mathrm{~A}$ review about the proportion of international travellers presenting travel-related problems exposed the scarcity of this type of information. $^{3}$

In Portugal, there is surveillance data and hospital case studies, which only expose the tip of the iceberg: ill people that looked for health care after arrival in Portugal. ${ }^{3-26}$

The increasing number of people travelling from Portugal to malaria endemic countries, especially African Portuguese-speaking countries, needs attention and surveillance. The number of imported malaria cases has been increasing, but these numbers may be underestimated by three to four times. ${ }^{4-6}$

To the best of our knowledge, only two studies in Portugal have described the proportion of travellers who acquired health problems during travel. The first one analysed 174 children under 16 years of age attending a travel clinic between 2002 and 2007, of whom $21.8 \%$ acquired diarrhoea. ${ }^{27}$ The other study showed that among 175 adults travelling between 2007 and 2008 for more than three months to Angola, $54.3 \%$ acquired diarrhoea, $18.9 \%$ presented fever, $15.4 \%$ declared having had malaria and the median adherence to malaria chemoprophylaxis was 90 days. ${ }^{28}$

The Institute of Hygiene and Tropical Medicine (IHMT) has existed since the beginning of the $20^{\text {th }}$ century and was the national reference for all international health problems. After the independence of the Portuguese colonies, it was integrated into the University. Since 2008, the IHMT expanded travel health clinics through a partnership with ADMT, Associação para o Desenvolvimento da Medicina Tropical (Association for the Development of Tropical Medicine). ${ }^{29}$ Although this partnership implies that clinics are more expensive than those in other international travel vaccination centres of the Portuguese National Health System, a survey in $2012^{30}$ showed that IHMT/ADMT is the largest travel health clinic in Portugal. The clinic offers services of pre and post travel consultation. In 2016 the clinic attended 9750 adults in pre-travel consultation and 10703 in 2017.

The main objective of this study was to characterize the perceived health problems of travellers, including their proportion, during and up to six months after travel on a cohort of travellers with a pre-travel consultation at IHMT/ADMT. We also aimed to characterize perceived health problems according to the characteristics of travellers (age group, gender, educational qualifications) and travel characteristics (reason for travel, travel destination, duration, single or multiple destinations) and uptake of preventive measures.

\section{MATERIAL AND METHODS}

This is a prospective observational study. Participants were recruited among travellers attending IHMT/ADMT pretravel clinic by the six physicians participating in the study, between May 2016 and April 2017. Eligible travellers had to be 18 years of age or older on the day of consultation, intended to remain at the destination for five or more days or less than three months and give their consent to participate in our study.

The recruited travellers were interviewed by telephone, three and six months after arrival, using structured questionnaires. Data on intended travel dates, destination, age and sex of travellers were collected by physicians. To ensure that the interviewer applied the questionnaire in a similar way to all respondents, all conversations were described in a written script, including introduction, practical explanations, questions and acknowledgements. The questionnaire, applied three months upon return, included information on: educational qualifications; final destination(s) of travel; duration of travel; date of departure from and return to Portugal; reasons for travel; health problems during or after travel, namely diarrhoea, fever, nausea/vomiting, skin problems, accident/trauma or others; vaccines; malaria chemoprophylaxis, related compliance and adverse effects; stand-by treatment, changes in travel plans because of diarrhoea; seeking health care during and after travel in case of fever.

The second questionnaire, applied six months after returning, was focused on the understanding of long-term consequences, such as a possible occurrence of malaria and related healthcare seeking behaviour. It included information on health problems that the participant thought could be related to travel since the last phone interview: fever, diarrhoea, nausea and healthcare seeking behaviour and final diagnosis.

The questionnaires were based on a literature review. A pre-test allowed to estimate response time, to evaluate the understanding of questions and to make some changes to language according to results and suggestions obtained.

Participants were contacted at the indicated time of expected availability. After two unsuccessful phone calls a text message was sent to schedule another call to collect information. After four telephone calls and one text message with no response, the enrolled participant was considered a non-response. The last telephone interview was done in February 2018.

A code number was used to identify the participant in the database and only two researchers knew the correspondence with the identification of travellers.

The study was approved by the IHMT Ethics Committee (No. 3-2016).

Diarrhoea was classified into two categories: 'traveller's diarrhoea' and 'diarrhoea'. 'Traveller's diarrhoea', as described previously, ${ }^{31-33}$ was considered as the development of three or more episodes of unshaped or liquid faeces per day, followed by one additional symptom (fever, abdominal cramps or pain, nausea and vomiting, faeces with blood or headache), during travel to up to 14 days after returning. 
Episodes of unshaped or liquid faeces without the criteria above were simply considered as 'diarrhoea'.

Microsoft Excel 2010 spreadsheets were used to collect the raw data, while statistical analyses were performed in $\mathrm{IBM}^{\circledR}$ SPSS $^{\circledR}$ Statistics 25 . Absolute and relative frequencies (number and percentage of cases) were calculated by each categorical variable. Mean and standard deviation were used for symmetric continuous variables. Median and $\left(P_{25}-P_{75}\right)$ were presented for asymmetric continuous variables or for discrete or ordinal variables. KolmogorovSmirnov and Shapiro-Wilk tests were performed to assess normality of continuous variables. Homogeneity of variances of continuous variables for two or more groups was assessed by Levene test. After checking these assumptions, parametric tests ( $t$-student test or ANOVA) or nonparametric tests were used to compare two independent groups (Mann-Whitney test) or several groups (KruskalWallis test). The chi square test was used to explore the association between travel and the characteristics of travellers with overall health problems, fever and traveller's diarrhoea. In case of failure of assumptions of the chi square test, $p$ values were calculated by Fisher's exact test. In order to adjust for confounding, the magnitude of the associations was estimated by adjusted odds ratios obtained by multiple logistic regression models considering the binary dependent variables: "total health problems, during and until three months after travel" (yes/no), "fever during and until three months after travel" (yes/no) and "diarrhoea during and until three months after travel" (yes/no). The $p$ values and 95\% confidence intervals were calculated. A significance level (a) of $<0.05$ was considered.

\section{RESULTS}

A total sample of 387 travellers were recruited among individuals consulting with the physicians involved in the study, between May 2016 and April 2017. Three hundred and sixty-four $(94.1 \%)$ completed all the steps of the study. Non-res-ponders $(5.9 \%)$ were related to refusal to answer after travel, travel cancellations and wrong phone numbers. There were no losses of participants in the study between the first and second questionnaire.

Traveller's demographics, travel characteristics, travelacquired illnesses and adopted measures to prevent or treat those, according to medical advice, are detailed below.

\section{Traveller's demographics}

Males and females represented $54.9 \%$ and $45.1 \%$ of 364 enrolled travellers, respectively. Almost 60\% (59.9\%) of them were under 37 years of age (range: $18-84$ years old, mean $\pm \mathrm{s}$ : $36.6 \pm 11.74$ ). Table 1 shows that $87.9 \%$ presented a higher education level.

\section{Travel characteristics}

Africa and Asia were the preferred destinations for almost $90 \%$ of travellers $(89.1 \%)$, while $9.9 \%$ were travelling to Latin America. Business/employment (34.9\%), tourism/ vacation $(33.5 \%)$ and volunteering $(28.0 \%)$ were the main travel reasons. Almost all travellers (90.7\%), stayed in destination for 5 - 30 days [range: 4 - 90 days; median $\left(P_{25}-P_{75}\right)$ : 15 days (10 - 21)]. Four travellers, although having intended to stay for at least five days, stayed four days. From these four travellers, none reported health problems. Although the number of destinations could sometimes be higher, most travellers $(81 \%)$ had a single destination (Table 1$)$.

\section{Travel-acquired health problems up to three months af- ter travel}

At three months after travel, 143 travellers (39.3\%) referred at least one travel-acquired health problem. When questioned about the presence of specific symptoms such as fever, diarrhoea, nausea and vomiting, skin problems, accident or trauma or another symptom, 45 (12.4\%) reported unmeasured fever, 97 (26.6\%) diarrhoea, 18 (4.9\%) nausea and vomiting, six (1.6\%) skin problems and six (1.6\%) an accident or trauma. No other symptoms besides those were reported by any traveller (Table 2). One hundred and twenty-seven travellers (34.9\%) reported just one of the aforementioned symptoms, while 16 (4.3\%) mentioned two to four symptoms.

Table 1 highlights possible associations between travellers' demographics and travel characteristics and health problems (total) and each specific symptom - fever and diarrhoea. According to the fitted logistic regression models (Table 1) travel-acquired health problems were shown to be associated with age group and destination. Compared with the youngest, older travellers were less likely to have travelacquired health problems $[p=0.033$; ORa $=0.192,95 \%$ confidence interval $(\mathrm{Cl}):(0.042 ; 0.874)]$. Travellers to Latin America were almost 2.5 times more likely to have health problems than travellers to Africa $[p=0.019$; ORa $=2.451$; 95\% Cl: $(1.157 ; 5.193)]$.

\section{Specific symptoms}

Fever: Out of $45(12.4 \%)$ travellers who reported unmeasured fever, $34(75.6 \%)$ reported it during travel, of which $31(91.2 \%)$ were in the first week of travel. Of the 11 $(24.4 \%)$ travellers who mentioned fever after returning, six $(54.5 \%)$ had it in the first week and four (36.4\%) between eight and 30 days.

Significant statistical associations were found between fever and age group, reason for travel and travel duration (Table 1). Compared with the youngest, travellers aged between 38 and 57 were less likely to mention fever $[p=$ $0.019 ;$ ORa $=0.396 ; 95 \% \mathrm{Cl}(0.183 ; 0.858)]$. People visiting friends and relatives $[p=0.018 ; \mathrm{ORa}=6.861 ; 95 \%$ $\mathrm{Cl}(1.399 ; 33.660)]$, volunteering $(p=0.012 ; \mathrm{ORa}=3.414$; $95 \% \mathrm{Cl}(1.306 ; 8.924)]$ and travelling for businesses/employment $[p=0.029 ; \mathrm{ORa}=2.904 ; 95 \% \mathrm{Cl}(1.112 ; 7.582)]$ were, respectively, 6.8, 3.4 and 2.9 more likely to mention fever compared to tourists. People travelling for more than 30 days were almost 3 times more likely to mention fever than those travelling for less than a month $[p=0.020$; ORa $=2.986 ; 95 \% \mathrm{Cl}(1.186 ; 7.518)]$.

A hospital or healthcare centre was sought by three 


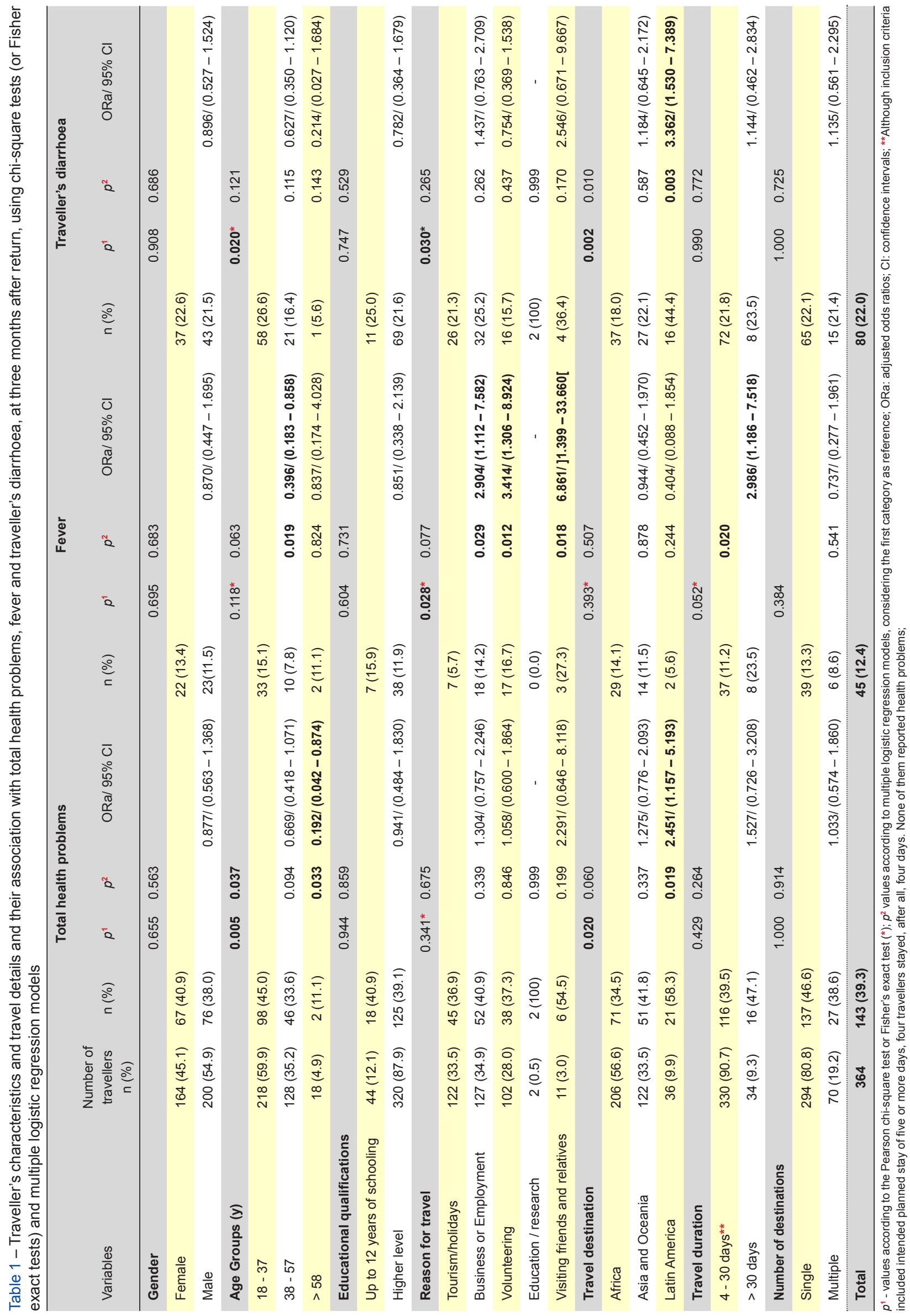


Table 2 - Health problems presented by 143 (39.3\%) travellers during and after travel, up to three months after travel

\begin{tabular}{lc}
\hline Health problems & $\mathbf{n}(\%)^{*}$ \\
\hline Diarrhoea & $97(26.6)$ \\
$\quad$ Traveller's diarrhoea & $80(21.9)$ \\
$\quad$ Non-traveller's diarrhoea & $17(4.7)$ \\
Fever & $45(12.4)$ \\
Nausea/ Vomiting & $18(4.9)$ \\
Skin problems & $6(1.6)$ \\
Accident or trauma & $6(1.6)$ \\
\hline
\end{tabular}

* proportion of the 364 travellers presenting the specific health problem

travellers $(8.8 \%)$ of the 34 who presented fever during travel, whilst nine $(81.8 \%)$ of those 11 with fever after returning did so. According to each study participant, a malaria diagnostic test was performed which, in all cases, was negative.

We also looked at data on the travellers who visited Sub-Saharan countries with disseminated high risk of malaria transmission, referred to here as high-risk malaria zones [HRMZ, list of countries provided as Appendix 1 (see Appendix 1: https://www.actamedicaportuguesa.com/revista/index.php/amp/article/view/14098/Appendix_01.pdf)]. Of the overall travellers reporting unmeasured fever, 29 travelled to HRMZ, of whom 23 (79.3\%) reported fever during travel and six $(20.7 \%)$ after returning. Two out of $23(6.9 \%)$ in the first group reported they looked for healthcare services, and similar behaviour was recorded for all of those in the second group $(6 / 6,100 \%)$.
Diarrhoea: Out of 97 travellers $(26.6 \%)$ who reported diarrhoea, $80(82.5 \%)$ filled the criteria for traveller's diarrhoea. The most common associated symptom was abdominal cramps or pain $(n=51 ; 63.8 \%)$, followed by nausea ( $n$ $=33 ; 41.3 \%)$ and vomiting $(n=33 ; 41.3 \%)$, fever $(n=24$; $30.0 \%)$ and headache $(19 ; 23.8 \%)$. None of the travellers reported faeces with blood.

Traveller's diarrhoea appeared after a mean of 4.9 days (range 1 - 22 days) after arrival at the destination, with a mean maximum number of daily dejections of 4.3 (range 3 - 8 dejections) and a mean duration of 2.8 days (range 1 - 6 days).

From those with traveller's diarrhoea, 73 (91.3\%) resorted to the stand-by-treatment which consisted in the use of antimotility loperamide drug $(n=65 ; 81.3 \%)$ and antibiotics ( $n=25 ; 31.3 \%$ ): only loperamide, 48 (60\%), only antibiotics, eight $(10 \%)$ and antibiotics associated with loperamide 17 (21.3\%).

All travellers who changed planned activities during travel due to diarrhoea, [12 (15\%)] had traveller's diarrhoea.

Traveller's diarrhoea was only associated with the travel destination (Table 1). People travelling to Latin America were 3.4 times more likely to get traveller's diarrhoea than those travelling to Africa $[p=0.003 ; \mathrm{ORa}=3.362 ; 95 \% \mathrm{Cl}$ $(1.530 ; 7.389)]$.

Nausea and vomiting, skin problems and accidents or trauma: These were found in $8.2 \%$ of travellers and were not associated with traveller demographics or travel characteristics. Accidents or trauma were due to spider bite,

Table 3 - Travellers' adherence to malaria chemoprophylaxis

\begin{tabular}{|c|c|c|c|c|c|}
\hline \multicolumn{3}{|c|}{ Adherence and reasons for interruption of chemoprophylaxis } & \multicolumn{3}{|c|}{ Chemoprophylaxis used by travellers } \\
\hline & & & \multirow{2}{*}{$\begin{array}{c}\begin{array}{c}\text { Mefloquine } \\
(\mathrm{n} / \mathrm{N})\end{array} \\
\\
82 \\
82 / 304(27.0 \%)\end{array}$} & \multirow{2}{*}{$\begin{array}{c}\text { Atovaquone } \\
\text { and Proguanil } \\
\text { Hydrochloride } \\
(\mathbf{n} / \mathrm{N}) \\
222 \\
222 / 304(73.0 \%)\end{array}$} & \multirow{2}{*}{$\begin{array}{l}\text { Total } \\
(\mathbf{N})\end{array}$} \\
\hline & & & & & \\
\hline \multicolumn{3}{|c|}{ Complete adherence * } & $\begin{array}{c}62 \\
62 / 82(75.6 \%)\end{array}$ & $\begin{array}{c}194 \\
194 / 222(87.4 \%)\end{array}$ & $\begin{array}{c}256 \\
256 / 304(84.2 \%)\end{array}$ \\
\hline \multirow[t]{4}{*}{ Non-adherence ** } & \multicolumn{2}{|c|}{ Non-adherence before travel } & 0 & 26 & 26 \\
\hline & \multicolumn{2}{|c|}{ Does not record periodicity/dosage } & 19 & 15 & 34 \\
\hline & \multicolumn{2}{|c|}{ Interrupted during travel } & 11 & 1 & 12 \\
\hline & \multicolumn{2}{|c|}{ Interrupted after travel } & 20 & 16 & 36 \\
\hline \multirow{9}{*}{$\begin{array}{l}\text { Reasons for } \\
\text { interruption of } \\
\text { chemoprophylaxis }\end{array}$} & \multirow[t]{8}{*}{ Adverse events } & Vomiting & 0 & 1 & 1 \\
\hline & & Nausea & 6 & 1 & 7 \\
\hline & & Malaise & 7 & 1 & 8 \\
\hline & & Tiredness & 6 & 0 & 6 \\
\hline & & Anxiety & 1 & 0 & 1 \\
\hline & & Lack of hearing & 12 & 0 & 12 \\
\hline & & Nightmares/ insomnia & 0 & 1 & 1 \\
\hline & & Mood changes & 2 & 0 & 2 \\
\hline & \multicolumn{2}{|l|}{ Peer advice } & 2 & 15 & 17 \\
\hline
\end{tabular}

* Complete adherence, when the traveller started taking malaria chemoprophylaxis before travel, maintained it throughout travel and after the return according to correct frequency and duration of specific drug; ${ }^{* *}$ Non-adherence was considered when there was any failure to take malaria chemoprophylaxis before, during or after travel. 
skin burn and abrasions due to sports practice or fall and motorcycle accident in six $(1.6 \%)$ travellers, but none reported the need to seek medical help.

Travel-acquired health problems up to six months after travel: During the phone call performed six months after travel, participants were asked about health problems that might have developed since the last interview and that, in their opinion, could be related to travel. Twenty travellers (5.5\%) responded affirmatively, all of whom had unmeasured fever; nine (45\%) also reported diarrhoea. On average, fever was noticed 20 days after the first phone interview (range of 6 - 45 days, mean of 20.3 days). Four (20\%) out of 20 sought healthcare, two of whom did malaria diagnostic testing: one tested positive. This traveller reported complete adherence to chemoprophylaxis (meaning that the traveller started taking the medication before travel, maintained it throughout and after returning, according to correct frequency and duration of the specific drug) and the fever and diagnosis of malaria occurred 3.5 months after return. From the 20 travellers declaring a health problem after six months of return, $55 \%$ travelled to a HRMZ. One traveller in this group sought medical help (malaria test negative).

Measures to prevent travel-acquired illnesses: chemoprophylaxis for malaria and vaccination

According to information provided by the participants, chemoprophylaxis for malaria was recommended for 304 travellers: 256 (84.2\%) declared a complete adherence. Non-adherence was considered if there was any failure to take it before, during or after travel. Out of the 304 travellers, $82(27.0 \%)$ used mefloquine and 222 (73.0\%) used the combination of atovaquone and proguanil hydrochloride. Table 3 shows the number of travellers who declared missing the prophylactic medication before travel and those who aborted the usage during and after travel. Reasons why travellers withdrew chemoprophylaxis are also shown. Adverse effects were responsible for chemoprophylaxis withdrawal in 20 people on mefloquine and one on atovaquone and proguanil hydrochloride.

Countries with widespread high risk of malaria transmission (HRMZ) were visited by 189 travellers, of whom 154 $(81 \%)$ reported to have taken chemoprophylactic medication. Out of those 154 travellers, $80.5 \%$ declared a complete adherence $(70 \%$ on mefloquine and $84.2 \%$ on atovaquone and proguanil hydrochloride groups), making up a total of $65.6 \%(124 / 189)$ claiming a complete adherence to malaria chemoprophylaxis.

Travellers were asked about vaccination schedule. Table 4 shows the type and number of related travel vaccines travellers referred to have received during the first phone interview. The most frequent referred vaccines were typhoid, hepatitis $A$, yellow fever and tetanus/diphtheria.

\section{DISCUSSION}

To the best of our knowledge, this was the first study conducted aimed at ascertaining the frequency and type of health problems experienced, during and after travel, by travellers aged 18 years old and over that attended the IHMT/ADMT travel consultation, with predicted time for stay of 5 - 90 days.

\section{Limitations of the study}

Failure to follow a random sampling method by all physicians may compromise the sample representativeness. However, the demographics and travel characteristics of travellers were similar to those of a previous systematic random sample study including 5290 medical registries from 33979 pre-travel consultations in 2013, 2014 and 2015 in the same consultation. ${ }^{34}$ Results were as follows: $63.6 \%$ travellers were male, $79 \%$ travelled to Africa, Angola was the main destination and most travellers stayed less than a month at their destination.

In both studies, the two main reasons for travelling are business/employment and tourism/holidays, with a slight decrease in the former and an increase in volunteering observed in our study. Data from 2013 - 2015 reflect a period of increased travel to Angola for work. Data from a 2012 study $^{30}$ showed that characteristics of travellers (and their travels) attending travel consultations in Portuguese public health units was very similar: males younger than 40 years old traveling for work to Africa (Angola as main destination) and staying for less than one month.

Official data in Portugal on Portuguese people travelling abroad $^{35}$ offers a different profile of travellers. For example, in 2017 , approximately $12.0 \%$ (1.26 million) of residents in Portugal travelled abroad, $57.4 \%$ on holidays, $21.4 \%$ visiting friends and relatives and $19.1 \%$ for business/employment. The main destination was Europe with only $6 \%$ of travels to the African continent, $8.8 \%$ to America and $3.1 \%$ to Asia and Oceania. ${ }^{36}$

In our study, a higher number of travellers had a higher educational level $(87.9 \%)$ when compared with the general Portuguese population $(18.1 \% \text { in } 2017)^{37}$ or among those travelling both inside the country and overseas $(23.8 \%$, in 2017). ${ }^{38}$ The IHMT/ADMT clinic is a public-private partnership, with consultations costing seven to ten times more compared to public services. However, we do not have information on the education level of travellers attending public

Table 4 - Vaccines travellers declared to have received, when asked three months after return

\begin{tabular}{lc}
\hline Vaccine & Number of travellers immunised \\
\hline Typhoid fever & 320 \\
Hepatitis A & 300 \\
Yellow fever & 265 \\
Tetanus/ Diphtheria & 222 \\
Hepatitis B & 208 \\
Japanese encephalitis & 101 \\
Rabies & 54 \\
Meningococcus, tetravalent & 15 \\
Poliomyelitis & 3 \\
\hline
\end{tabular}


health travel clinics and there is no income characterization of people travelling or attending travel clinics in Portugal. We admit that people with higher income may travel more and look for advice more often than average.

Our findings are not generalizable to travellers abroad from Portugal because IHMT/ADMT travellers might present a particular profile in terms of education and income.

Participants were recruited from a population that sought preventive counselling, vaccines, chemoprophylaxis and standby treatments that are specific and even mandatory to same destinations. These travellers might be more concerned with their health, which might contribute to an underestimation of health issues in this study, because they may be aware of the higher risk and severity of some diseases, and therefore looked for and adopted preventive measures. In that regard, a EuroTravNet study showed that the pre-travel consultation was associated with a decreased proportion of morbidity for Plasmodium falciparum, HIV and AIDS. ${ }^{2}$ On the other hand, a possible overestimation should be also considered, since people who are more concerned with their health may value any health problems more.

Questionnaires were applied three and six months upon return, because there was a concern with long term problems, such as malaria. Although travellers were told, during recruitment, about the objectives of the study and informed that questions on health problems would be asked, three and six months are a considerable period for follow up, which might have increased recall bias, contributing to underestimation of health problems. Social desirability bias may also be present.

\section{Proportion of international travellers acquiring travel- related health problems}

A review on the proportion of international travellers presenting travel-related problems was published during the data collection period of our study. ${ }^{3}$ The review included nine studies and, in contrast to our findings, a predominance of male travellers was only found in three of the nine studies reviewed, with a median age of 35 to 52 years, and most people travelled for tourism/holidays instead of business/employment. In our study, the most common destinations were also African and Asian regions, with the top five destinations being Angola, Mozambique, Thailand, Indonesia and São Tomé and Príncipe. Like most of the selected studies, the recruitment of participants took place during a pre-travel consultation, and the most frequent health problem was diarrhoea. In our study, the proportion of overall travellers that became ill was $39 \%$, which is less than the results from Angelo et al, ranging between 43\% - 79\% in the four studies selected as those providing the best estimate for travellers to middle and low-income countries. The range of existing proportions could probably be related to many factors, namely, i) study designs (sample selection and size methodology, different periods of time to follow up, recall bias), ii) type of population studied (pre-travel attendees, travellers at airports; reasons for travel; country of origin; education and income level; cultural aspects related to ad- herence to recommendations), iii) data collection method (self-registries with lower response rates and a possible bias of people with health problems), iv) different definitions of diseases in studies and pre-selection of health problems in structured instruments of data collection, v) destination countries (low and middle-income countries, travel season), vi) travel duration and, possibly, vii) cultural aspects of perceived disease. $^{3,27}$

\section{Malaria}

Malaria for non-immune people can be considered a medical emergency because of the risk of progressing to severe forms of disease, mainly when caused by Plasmodium falciparum. Malaria tests are not easily available in Portugal (in a healthcare setting only) and generally cannot be carried when travelling to remote areas. The general advice in pre-travel consultation is to look for medical care to perform a malaria test as early as possible if fever after 5 - 7 days of stay. In the case of fever, the proportion of people looking for healthcare after return was much higher than those looking for healthcare during travel. This is probably related to greater confidence in and better access to health care at home. In general, healthcare seeking behaviour was less than expected if individuals would follow general recommendations towards early diagnosis of malaria. Only $65.6 \%$ of travellers to HRMZ declared complete adherence to chemoprophylaxis for malaria. Adverse effects were responsible for withdrawal in a more substantial number of people in the mefloquine group, as expected ${ }^{39}$ Almost every traveller that claimed peer advising as a reason to withdraw malaria chemoprophylaxis was in this group of travellers to HRMZ.

In 2011, a study conducted in this same travel clinic, on a convenience sample of 253 travellers to malaria endemic areas for periods shorter than two months, concluded that the proportion of complete adherence was similar (62.1\%). ${ }^{40}$

Healthcare seeking in case of fever and low adherence to chemoprophylaxis, which was a common attitude during more recent years, may reflect that individuals do not consider malaria to be a potential serious disease, whose severity increases with a delayed diagnosis.

This is an area that needs better understanding and action, as most malaria deaths occurring in Portugal are avoidable. ${ }^{4,5}$

\section{Diarrhoea}

As mentioned before, diarrhoea is one of the most common symptoms reported by travellers. In our clinic, it is usual practice to prescribe standby treatment, most often with loperamide and an antibiotic, in line with the international guidelines. ${ }^{41}$ This is an area of growing concern, as diarrhoea acquired during travel abroad and treated with antibiotics contributes to the emergence and dissemination of antimicrobial resistance. ${ }^{42-44}$ These risks are explained by many practitioners in view of travellers' cautious antibiotics use. Our study showed that among travellers with traveller's diarrhoea criteria, $31.3 \%$ used antibiotics, of which 
21.3\% used antibiotics and loperamide. To the best of our knowledge, no data exists on the imported enteric resistant microorganisms in Portugal. This is the first data on antibiotic use in traveller's diarrhoea. Further studies are needed to ascertain how travellers' attitude towards antibiotics use for traveller's diarrhoea is linked to the recommendations received as pre-travel advice.

\section{Vaccines}

At the time of the three months telephone interview, reported vaccines, presented in Table 4, may reflect: i) the changing epidemiological pattern of hepatitis A in Portugal, with a low prevalence in young people ${ }^{45-47}$ increasing the need for vaccination in those leaving the country to endemic areas; ii) the opportunity for updating Portuguese vaccination schedules (tetanus/diphtheria) at pre travel clinic; iii) the exclusive availability of typhoid and yellow fever vaccines at international travel vaccination centres such as the IHMT/ADMT; iv) most frequent destinations.

\section{Visiting friends and relatives}

Portugal has an important resident community from Portuguese-speaking African countries (total of 80736 in 2018, from Cape Verde, Angola, Guinea Bissau, São Tomé and Principe and Mozambique) and Brazil (104 504).48 These countries offer health risks related with yellow fever and malaria, that are particularly challenging to second generation visiting relatives. The small proportion of $3 \%$ of travellers visiting friends and relatives found in our study might represent an unmet health need in travel medicine in Portugal, as it is recognised for the rest of Europe. ${ }^{2}$ In Portugal, this group needs additional characterization.

\section{CONCLUSION}

This is the first study attempting to characterize health problems during and after travel in adult travellers attending the IHMT/ADMT pre-travel consultation (aged over 18 and predicted time of stay 5 - 90 days). Our most common traveller profile was male, less than 37 years old, with a higher education degree and travelling to Africa on business.

Around $40 \%(39.3 \%)$ of travellers confirmed some health problem during or up to three months after travel, diarrhoea being the most frequent problem, followed by perceived fever. A malaria case was diagnosed 3.5 months after return. The communication on malaria risk does not seem to be translated into appropriate action. The lack of healthcare demand in the presence of fever and the low complete adherence to malaria chemoprophylaxis needs better understanding and action, as most described malaria cases and deaths occurring in Portugal could be prevented.

Regarding overall health problems, younger travellers

\section{REFERENCES}

1. Karin L, Torresi, J, Libman M, Cramer J, Castelli F, Schlagenhauf P, et al. GeoSentinel surveillance of illness in returned travelers, 2007-2011. Ann Intern Med. 2013;158:456-68.

2. Schlagenhauf P, Weld L, Goorhuis A, Gautret P, Weber R, Von Sonnenburg $\mathrm{F}$ et al. Travel-associated infection presenting in Europe and those travelling to Latin America would need more attention, as those were found to become ill more frequently.

However, the limitations of our study described above recommend caution when interpreting results. Therefore, further research is needed, with inclusion of other centres practicing travel medicine in Portugal, both in the pre-travel setting and others (for example in airports), in order to better understand the health risks associated with traveller's characteristics and destinations. This would contribute to improve pre-travel advice, health promotion and decrease avoidable morbidity.

\section{AUTHORS CONTRIBUTION}

CC: Conceptualization, methodology, investigation, data curation, formal analysis, visualization, validation, project administration, draft of the paper, review and editing.

MM: Formal analysis, visualization, draft of the paper, review and editing.

NP, RT: Conceptualization, methodology, investigation, review and editing.

LG: Conceptualization, methodology, formal analysis, validation, review and editing.

$A A, E B, C A$ : Investigation, review and editing.

FP: Conceptualization, methodology, investigation, draft of the paper, review and editing.

\section{ACKNOWLEDGEMENTS}

The authors express their gratitude to all travellers participating in this study, to IHMT/ADMT travel clinic for allowing and supporting the study, Professor Inês Fronteira, IHMT, for comments on design of the study and questionnaires.

\section{PROTECTION OF HUMANS AND ANIMALS}

This research had the clearance of the IHMT' Ethics Commission. All procedures were followed according to the 2013 Helsinki Declaration of the World Medical Association.

\section{DATA CONFIDENTIALITY}

The authors declare having followed the protocols in use at their working center regarding patients' data publication.

\section{COMPETING INTERESTS}

The authors have declared that no competing interests exist.

\section{FUNDING SOURCES}

This research did not receive any specific grant from funding agencies in the public, commercial, or not-for-profit sectors.

(2008-12): an analysis of EuroTravNet longitudinal, surveillance data, and evaluation of the effect of the pre-travel consultation. Lancet Infect Dis. 2015;15:55-64.

3. Angelo KM, Kozarsky PE, Ryan ET, Chen LH, Sotir M. What proportion of international travellers acquire a travel-related illness? A review of the 
literature. J Travel Med. 2017;24:1-8.

4. Fonseca AG, Dias SS, Baptista JL, Torgal J. The burden of imported malaria in Portugal 2003 to 2012. J Travel Med. 2014;21:354-6.

5. Fonseca AG, Dias S, Baptista J, Torgal J. Imported malaria in Portugal 2000-2009: a role for hospital statistics for better estimates and surveillance. Malar Res Treat. 2014;110:345-53.

6. Direção-Geral da Saúde. Doenças de declaração obrigatória 2012 2015. Volume I. Lisboa: DGS; 2016. [consultado 2019 dez 17]. Disponível em: https://www.dgs.pt/portal-da-estatistica-da-saude/ diretorio-de-informacao/diretorio-de-informacao/por-serie-721256-pdf. aspx?v=11736b14-73e6-4b34-a8e8-d22502108547.

7. Parreira R, Conceição C, Centeno-Lima S, Marques N, Saraiva da Cunha J, Abreu C, et al. Angola's 2013 dengue outbreak: clinical, laboratory and molecular analyses of cases from four Portuguese institutions. J Infect Dev Ctries. 2014;8:1210-5.

8. Monteiro M, Vilaça A, Pimentel T, Estrada A. Malária - estudo retrospectivo de 12 anos no Hospital de Braga. Rev Med Int. 2015;22:190-5.

9. Santos LC, Abreu C, Xerinda SM, Tavares M. Severe imported malaria in an intensive care unit: a review of 59 cases. Malar J. 2012;11:96.

10. Palma dos Reis I, Serafim C, Valério B, Araújo R, Silvestre J, Mendes $\mathrm{V}$, et al. Malária grave importada em doentes críticos. Acta Med Port. 2012;25:271-6.

11. Freira S, Luis C, Brito MJ, Santos C, Carreiro MH, Ferreira GC, et al. Internamento por malária importada em crianças, em dois hospitais da Grande Lisboa. Acta Pediatr Port. 2009;40:65-8.

12. Carreira J, Casella MI, Ascenção B, Luis NP, Gonçalves AC, Brito $\mathrm{AP}$, et al. Acute disseminated encephalomyelitis, a rare post-malaria neurological complication: case report and review of the literature. Travel Med Infect Dis. 2019;28:81-5.

13. Ornelas É, Maia R, Carvalho R, Dória MC. Malária - uma causa rara de colecistite aguda. Rev Port Doenças Infecciosas. 2018;14:35-8.

14. Pires A, Capela C, Gouveia P, Mariz JA. Severe malaria - clinical case. Rev Port Pneumol. 2011;17:41-3.

15. Carvalho D, Azevedo C, Coelho R, Ferreira A, Figueiredo P, Santos L, et al. Colecistite aguda alitiásica num doente com malária grave. Acta Med Port. 2011;24:S631-4.

16. Santos A, Calé E, Dacheux L, Bourhy H, Gouveia J, Vasconcelos P Fatal case of imported human rabies in Amadora, Portugal, August 2011. Euro Surveill. 2012;17:pii=20130.

17. Figueiredo J, Santos A, Clemente H, Lourenço A, Costa S, Grácio MA, et al. Schistosomose e apendicite aguda. Acta Med Port. 2014;27:3969.

18. Azinhais $P$, Silva L, Conceição $P$, Pereira B. Schistosomíase urinária: um caso clínico diagnosticado em Portugal. Acta Urológica. 2009;26:5562.

19. Murinello N, Germano P, Mendonça C, Campos A, Grácio A. Liver disease due to Schistosoma Guineensis - a review. J Port Gastrenterol. 2006;13:97-104.

20. Mesquita NF. Polipose cólica por Shistosoma mansoni - caso clínico e revisão da literatura. J Port Gastrenterol. 2004;11:89-95.

21. Zé-Zé L, Prata MB, Teixeira T, Marques N, Mondragão A, Fernandes $\mathrm{R}$, et al. Zika virus infections imported from Brazil to Portugal, 2015. IDCases. 2016;4:46-9.

22. Sassetti M, Zé-Zé L, Franco J, Cunha J, Gomes A, Tomé A, et al. First case of confirmed congenital Zika syndrome in continental Africa. Trans R Soc Trop Med Hyg. 2018;112:458-62.

23. Silva A, Méndez J, Abreu M, Sarmento e Castro R. Febre num doente regressado de Angola. Rev Port Doenças Infeciosas. 2013;9:41-5.

24. Ferreira A, Silva A, Cruz M, Sabino R, Veríssimo C. Labial lesion in a Portuguese man returned from Brazil - the role of molecular diagnosis. Travel Med Infect Dis. 2018;22:80-1.

25. Borges-Costa J, Martins ML. Trichophyton erinacei skin infection after recreational exposure to an elephant in Southeast Asia. Pathog Glob Health. 2014;108:58-9.

26. Soares S, Ferraz de Liz C, Cardoso AL, Machado A, Cunha J, Machado L. Larva Migrans cutânea - apresentação típica de dois casos clínicos. Nascer e Crescer. 2018;27:46-9.

27. Silva FG, Figueiredo A, Varandas L. Travelers' diarrhea in children visiting tropical countries. J Travel Med. 2009;16:53-4.

28. Moreira A. Avaliação da adesão à quimioprofilaxia da malária em viajantes de longa duração para Angola. Master thesis. Porto: Instituto de Ciências Biomédicas Abel Salazar, Universidade do Porto; 2009.

29. Instituto de Higiene e Medicina Tropical. Consulta do viajante. Lisboa:
IHMT NOVA. [consultado 2020 jan 30]. Disponível em: https://www.inmt. unl.pt/consulta-do-viajante.

30. Conceição $\mathrm{C}$, Teodósio $\mathrm{T}$, Pereira $\mathrm{F}$, Racha-Pacheco $\mathrm{R}$, Araújo $\mathrm{C}$ Seixas J, et al. Medicina do viajante em Portugal: workshop e criação da Sociedade Portuguesa de Medicina do Viajante. An Inst Hig Med Trop. 2014;13:91-4

31. Vilkman K, Pakkanen SH, Lääveri T, Siikamäki H, Kantele A. Travelers' health problems and behavior: prospective study with post-travel followup. BMC Infect Dis. 2016;16:328.

32. Hill DR. Health problems in a large cohort of Americans traveling to developing countries. J Travel Med. 2000;7:259-66.

33. Steffen R. Epidemiology of travellers' diarrhea. J Travel Med. 2017;24:S2-5

34. Portugal-Calisto P, Conceição C, Pereira F, Teodósio R. Travelers profile in travel consultations at a university in Lisbon - a cross sectional study. Poster presented at CISTM15, Conference of the International Society of Travel Medicine. Barcelona: ISTM, 2017

35. Instituto Nacional de Estatística. Estatísticas do Turismo 2017. Lisboa: INE; 2018. [consultado 2019 dez 17]. Disponível em: https://www.ine.pt/ xportal/xmain?xpid=INE\&xpgid=ine_publicacoes\&PUBLICACOESpub_ boui=320462327\&PUBLICACOESmodo=2.

36. Instituto Nacional de Estatística, PORDATA. Viagens turísticas de residentes: total e por destino principal. [updated 2018 dec 4]. [consultado 2019 dez 17]. Disponível em: https://www.pordata.pt/Portugal/Viagens+ tur\%c3\%adsticas+de+residentes+total+e+por+destino+principal-2550.

37. Instituto Nacional de Estatística, PORDATA. População residente com 15 e mais anos por nível de escolaridade completo mais elevado (\%) [actualizado 2019 jun 14]. [consultado 2019 dez 17]. Disponível em: https://www.pordata.pt/Portugal/Popula\%c3\%a7\%c3\%a3o+residente+c om $+15+e+$ mais + anos + por $+n \% c 3 \%$ advel+de+escolaridade+completo + mais+elevado+(percentagem)-884.

38. Instituto Nacional de Estatística, PORDATA. População residente que viajou em turismo: total e por nível de instrução (\%) [actualizado 2019 ago 5]. [consultado $2019 \mathrm{dez}$ 17]. Disponível em: https://www.pordata. pt/Portugal/Popula\%c3\%a7\%c3\%a3o+residente+que+viajou+em+turis mo+total+e+por+n\%c3\%advel+de+instru\%c3\%a7\%c3\%a3o+(percenta gem)-2618.

39. Tickell-Painter M, Maayan N, Saunders R, Pace C, Sinclair D Mefloquine for preventing malaria during travel to endemic areas. Cochrane Database Syst Rev. 2017;10:CD006491.

40. Tavares I. Concepções do viajante e adesão à quimioprofilaxia da malária. Dissertação de Mestrado. Lisboa: Instituto de Higiene e Medicina Tropical - Universidade Nova de Lisboa, Portugal, 2011.

41. Riddle M, Connor B, Beeching N, DuPont HL, Hamer DH, Kozarsky P, et al. Guidelines for the prevention and treatment of travelers' diarrhea: a graded expert panel report. J Travel Med. 2017;24:S63-80.

42. Arcilla $M$, Hattem J, Haverkate M, Bootsma M, Van Genderen $P$ Goorhuis A, et al. Import and spread of extended-spectrum $\beta$-lactamase producing Enterobacteriaceae by international travellers (COMBAT study): a prospective, multicentre cohort study. Lancet Infect Dis. 2017;17:78-85

43. Woerther PL, Andremont A, Kantele A. Travel-acquired ESBL-producing Enterobacteriaceae: impact of colonization at individual and community level. J Travel Med. 2017;24:S29-34.

44. Kantele A. A call to restrict prescribing antibiotics for travellers' diarrhea - travel medicine practitioners can play an active role in preventing the spread of antimicrobial resistance. Travel Med Infect Dis. 2015;13:2134.

45. European Centre for Disease Prevention and Control. Hepatitis A virus in the EU/EEA, 1975-2014. Stockholm: ECDC; 2016.

46. Silva A, Passadouro R, Rodrigues R, Pascoal D, Soares F. Imunidade para o vírus da hepatite A: vigilância de onze anos (2002-2012) numa consulta de medicina das viagens da região centro de Portugal. Rev Port Doenças Infecciosas. 2018;14:7-12.

47. Rocha S, Tejo S, Ferreira E, Trindade L, Rabadão E, Marques N, et al. Seroprevalência do anticorpo do vírus na hepatite $A$ em viajantes portugueses: um novo Pparadigma. Acta Med Port. 2017;30:534-40.

48. Instituto Nacional de Estatística, Serviço de Estrangeiros e Fronteiras / Ministério da Administração Interna, PORDATA. População estrangeira com estatuto legal de residente: total e por algumas nacionalidades [actualizado 2019 jul 1]. [consultado 2019 dez 17]. Disponível em: https://www.pordata.pt/Portugal/Popula\%c3\%a7\%c3\%a3o+estrangeira +com+estatuto+legal+de+residente+total+e+por+algumas+nacionalida des-24. 